\title{
Companion Crop and Planting Configuration Effect on Onion
}

\author{
Harlene M. Hatterman-Valenti ${ }^{1}$ and Paul E. Hendrickson ${ }^{2}$
}

ADDITIONAL INDEX WORDs. interspecific competition, reservoir tillage, living mulch, Allium cepa, Hordeum vulgare, Brassica napus

Summary. Field trials were conducted to evaluate the effect of planting configurations (raised bed and no bed) and reservoir tillage on onion (Allium cepa) yield and grade when a cereal grass or cool-season broadleaf species was used as a companion crop. Total onion yield, the number of plants harvested, percentage of single centers, and cull-sized bulb yields did not differ among planting configurations. However, planting onion seed in raised beds with reservoir tillage resulted in more large-diameter bulbs compared to planting without a bed configuration. Raised beds also had fewer small-sized bulbs than the non-bed configuration. Companion crop influence on onion yield and grade varied among environments (location plus year). In general, canola (Brassica napus) as a companion crop increased the yield of small-sized bulbs and decreased total yield and the yield of large-sized bulbs. These results were attributed to poor canola control from the initial bromoxynil plus oxyfluorfen application because each label restricts application until onions have reached the two true-leaf stage. Onion yield and grade with barley (Hordeum vulgare) as a companion crop was similar to that of onion with no companion crop except during 2002 (Carrington) when rain delayed the postemergence grass herbicide application and lowered onion yield.

$\mathrm{V}$ egetable production using raised beds is a common production method in many regions of the United States. Wilkes and Hobgood (1969) were some of the first researchers to examine the use of a raised bed on cotton (Gossypium hirsutum) production. Many warmseason vegetables are grown on raised beds and plastic mulch since higher soil temperatures can be attained when the two are used together (Locher et al., 2003). In the southeastern states, raised beds are used to facilitate drainage in high rainfall areas and provide channels for furrow irrigation (Bracy et al., 1993). However, in the northern Great Plains region, high rainfall events rarely occur, furrow irrigation is not used, and planting into conventional flat seedbeds is common.

In this area, most of the irrigated

${ }^{1}$ Assistant Professor, Department of Plant Sciences, North Dakota State University, 166 Loftsgard Hall, Fargo, ND 581055051. To whom reprint requests should be directed; e-mail: addresss: h.hatterman. valenti@ndsu.edu.

${ }^{2}$ Research Specialist, Carrington Research /Extension Center, PO Box 219, Carrington, ND 58421-0219.

The authors wish to thank the North Dakota State Board of Agricultural Research and Education for financial support of this research. The use of products named in this publication does not imply endorsement nor criticism of similar ones not mentioned. acres use overhead sprinkler irrigation on coarse, low organic matter, sandy soils, which are subject to wind and water erosion. Onion planted without a quick-emerging companion crop is prone to wind damage and "blow-out" as frequent high wind conditions occur during spring. Cereal grasses are good companion crops for onion because they have upright growth and can be selectively controlled. Annual crucifer crops such as canola may also provide companion crop protection needed by onion since germination and rosette growth occurs quickly.

Reservoir tillage in combination with overhead sprinkler irrigation is a common practice in potato (Solanum tuberosum) production (Alva et al., 2002). Reservoir tillage uses a combination chisel with a paddle wheel to implant small reservoirs that impound water (Jones and Stewart, 1990). The small reservoirs reduce runoff and cap-

Units

To convert

U.S. to $\mathrm{SI}$ multiply by

0.4047

0.3048

2.5400

25.4000

1.1209

2.2417

$\left({ }^{\circ} \mathrm{F}-32\right) \div 1.8$

$\begin{array}{lll}\text { U.S. unit } & \text { SI unit } & \begin{array}{l}\text { To convert } \\ \text { SI to U.S., } \\ \text { multiply by }\end{array} \\ \text { acre(s) } & \text { ha } & 2.4711 \\ \mathrm{ft} & \mathrm{m} & 3.2808 \\ \text { inch(es) } & \mathrm{cm} & 0.3937 \\ \text { inch(es) } & \mathrm{mm} & 0.0394 \\ \mathrm{lb} / \mathrm{acre} & \mathrm{kg} \cdot \mathrm{ha}^{-1} & 0.8922 \\ \text { ton/acre } & \mathrm{Mg} \cdot \mathrm{ha}^{-1} & 0.4461 \\ { }^{\circ} \mathrm{F} & { }^{\circ} \mathrm{C} & \left(1.8 \times{ }^{\circ} \mathrm{C}\right)+32\end{array}$


ture rainfall to increase yields. Reservoir tillage has been shown to increase corn (Zea mays) and potato yields (Alva et al., 2002; Howell et al., 2002). However, both crops typically are planted in wide rows and in a flat seed bed.

The objective of this study was to determine the effect of planting configurations (raised bed and no bed) and the reservoir tillage on onion yield and grade when a cereal grass or cool-season broadleaf species is used as a companion crop.

\section{Materials and methods}

Field trials were conducted at the Carrington Research/Extension Center (CREC) near Carrington, N.Dak., and the Horticulture Research and Arboretum (HRA) site near Absaraka, N.Dak. The soil at CREC is a Heimdal silt loam (coarse-loamy, mixed, superactive, frigid Calcic Hapludolls) with $\mathrm{pH} 7.5$ and $2.7 \%$ organic matter. The HRA site has a Renshaw sandy silt loam (sandy-skeletal, mixed, superactive, frigid Calcic Hapludolls) with $\mathrm{pH} 7.7$ and $2.9 \%$ organic matter. The previous crops at CREC and HRA sites were wheat (Triticum aestivum) and potato, respectively.

Fields were chiseled in the fall and again in the spring prior to bed shaping. Two paired rows of 'Teton' onion seed were planted on 6 - $\mathrm{ft}$ beds using a precision belt planter (Stanhay S870, Stanhay Webb, Ltd., Newmarket, Suffolk, U.K.) set at 104,000 seeds/acre at CREC and 144,000 seeds/acre at the HRA. Paired rows were planted 17 May, 2 May, and 22 Apr. at CREC during 2002 and 2003, and HRA during 2003, respectively, with pair row spacing on 16-inch centers and 4-inch spacing between each row pair.

Companion crops of barley ( $\mathrm{Hor}^{-}$ deum vulgare) or canola were planted parallel to the onion rows as single rows, about 5 inches on each side of the paired onion rows immediately following onion planting. Barley was planted at $54 \mathrm{~kg} \cdot \mathrm{ha}^{-1}$ and canola at 8 $\mathrm{kg} \cdot \mathrm{ha}^{-1}$ using a single-row cone planter. Reservoir tillage treatments were simulated with a spade on 11,7 , and 2 July at CREC during 2002 and 2003, and HRA during 2003, respectively, because plot size restricted proper implementation. Granular matrix sensors and thermisters (Watermark Soil Moisture Sensors, model 200SS; Irrometer Co., Riverside, Calif.) were installed into plots at 6- and 12-inch depths about 4 weeks after planting. Each sensor was placed between a double line and between four plants. All sensors were connected to a datalogger that recorded measurements on a 4-h interval.

Experimental design was a randomized complete block with a split plot arrangement, replicated four times. Planting configurations (bed and no bed) with or without reservoir tillage were the main plots, and companion crops (no crop, barley, and canola) were the sub-plots. Experimental units consisted of four paired rows, $20 \mathrm{ft}$ long. Appropriate fertilization, and weed and insect control protocols were followed. Water was applied by overhead sprinkler irrigation as needed. A postemergence application of clethodim at $0.125 \mathrm{lb} /$ acre a.i. or sethoxidim at $0.28 \mathrm{lb} /$ acre a.i. was used to control barley. Barley height at the time of herbicide application was 36 to $41 \mathrm{~cm}$ at CREC during 2002, 15 to $20 \mathrm{~cm}$ at CREC during 2003, and 18 to $25 \mathrm{~cm}$ at HRA during 2003 . Bromoxynil plus oxyfluorfen $(0.25+$ $0.12 \mathrm{lb} /$ acre a.i.) was applied postemergence to two- and five-leaf onion for canola and other broadleaf weed control. Canola height at the time of the initial broadleaf herbicide application was 15 to $20 \mathrm{~cm}$, and 46 to 61 $\mathrm{cm}$ during the second application. All onions within the two middle paired rows were pulled, topped, and cured in a forced-air drier or forced-air ventilated room on 8 Oct., 29 Sept., and 7 Oct. at CREC in 2002 and 2003, and HRA during 2003, respectively. After curing, grading was done by hand according to diameter: small $(<2.25$ inches), medium (2.25-3 inches), and large or jumbo (>3 inches). All split and diseased bulbs were considered culls regardless of bulb diameter. Twenty randomly selected bulbs with a diameter of at least 3 inches were used to determine the percentage of singlecenter bulbs. Single-center bulbs were determined by cutting equatorially through the bulb middle and, if multiple-centered, measuring the long axis of the inside diameter of the first single ring. If the diameter of the first single ring was $<1.5$ inches, the bulb was considered single-centered.

Data were analyzed using the general linear model to test single-factor effects and interactions (SAS Institute, Cary, N.C.). Planting configurations and companion crops were considered fixed effects, whereas environment (location plus year) was considered a random effect (McIntosh, 1983). Means were separated with Fisher's protected least significant difference at $P \leq 0.05$. Nontransformed data for percent single centers are presented because the arcsine square-root transformation did not affect data interpretation.

\section{Results and discussion}

The three-way interaction between planting configurations, companion crop, and environment and two-way interaction between planting configuration and companion crop was nonsignificant for onion total yield and grade. Planting configuration did not affect total yield, plant stand, or the percentage of single centers (Table $1)$. However, planting onion seed in raised beds with reservoir tillage did result in more large-diameter bulbs compared to seeds planted without a bed configuration. There were also more medium-sized bulbs with no-bed planting plus reservoir tillage compared to a raised bed planting with or without reservoir tillage and more small-sized bulbs with no-bed planting compared to raised beds. Even though the total yield did not differ between planting configurations, the proportion of each onion bulb grade to the total did vary. The larger number of small-sized bulbs as a percentage of the total for the no-bed plus reservoir tillage treatment $(23 \%)$ was greater than the raised-bed plus reservoir tillage treatment (13\%), whereas the percentage of large bulbs from the raised-bed plus reservoir tillage treatment (57\%) was greater than the $43 \%$ for the no-bed treatment (data not shown).

Raised beds are commonly used in vegetable production to increase crop yield. Kumar et al. (2001) showed that growing tomato (Lycopersicon esculentum) on raised beds increased mean fruit weight, fruit diameter, number of fruit and fruit yield per plant, and marketable fruit yield compared to planting on a flat bed. Likewise, pepper (Capsicum frutescens) yields were greater from direct-seeding into raised beds compared to flat ground (Cavero et al., 1996). However, Bhattarai and Subedi (1996) reported that 'Red Creole' onion yield was similar when grown in a raised or sunken bed. Dry bean (Phaseolus vulgaris) yield also did not differ when grown on raised 
bed or flat ground (Russo, 1995). Agricultural crops such as wheat and field corn also have shown no benefit in seed yield or quality when planted on raised beds compared to flat ground or no-bed planting (Fahong et al., 2003; Mascagni et al., 1995; Sharma and Saxena, 2002) unless flood irrigation was used to water the crop (Sharma et al., 2004).

Raised beds have been used for more than 30 years, primarily in the southern U.S., to facilitate drainage in high rainfall areas, provide channels for furrow irrigation, and warm the soil faster in order to take advantage of early spring markets (Bracy et al., 1993; Wilkes and Hobgood, 1969). Soil water tensions and soil temperatures were not monitored until onion emerged; thus, soil water or temperature differences during germination were not determined. However, soil water potentials and soil temperatures averaged over the three sites during June and July were similar among raised beds and no beds, indicating that any soil water and soil temperature differences that might have existed after planting due to seed bed preparation differences, had disappeared by onion emergence (data not shown).

A significant environment by companion crop interaction occurred for most yield variables. Onion planted with canola as a companion crop produced more small-sized bulbs and fewer medium- and large-sized bulbs in 2002 compared to other companion crop treatments (Table 2). Onion seed planted with barley as a companion crop in 2002 produced more smallsized bulbs and fewer large-sized bulbs than did the no-companion crop. Total bulb yields from within the barley or no-companion crop treatments were about three times greater than the canola treatments in 2002 and were related to the greater number of plants harvested. However, the smaller bulbs from the canola treatment did have a much higher percentage of single centers.

Onion yields from no-companion crop and barley treatments were similar at CREC during 2003 (Table 2). Smallsized bulbs were greater in the canola treatment compared to no-companion crop, while the total yield was again lowest within the canola treatment. Better growing conditions during 2003 (fewer days with temperatures $>29$ ${ }^{\circ} \mathrm{C}$ and reduced night temperatures)

Table 1. The effect of planting configuration on onion yield and grade at Carrington, N.Dak., during 2002 and 2003, and Absaraka, N.Dak., during 2003.

\begin{tabular}{|c|c|c|c|c|c|c|c|}
\hline \multirow{2}{*}{$\begin{array}{l}\text { Planting } \\
\text { configuration }\end{array}$} & \multicolumn{5}{|c|}{ Onion yield ${ }^{\mathrm{z}}$} & \multirow{2}{*}{$\begin{array}{l}\text { Single } \\
\text { centers }\end{array}$} & \multirow{2}{*}{$\begin{array}{c}\text { Bulb } \\
\text { no. }\end{array}$} \\
\hline & Small & Medium & Large & Cull & Total & & \\
\hline & \multicolumn{5}{|c|}{$\left(\mathrm{Mg} \cdot \mathrm{ha}^{-1}\right)^{\mathrm{y}}$} & $(\%)$ & (1000/ha) \\
\hline Raised bed & $6.4 \mathrm{a}^{\mathrm{w}}$ & $12.0 \mathrm{~b}$ & $32.1 \mathrm{ab}$ & $1.6 \mathrm{a}$ & $51.9 \mathrm{a}$ & $42 \mathrm{a}$ & $210 \mathrm{a}$ \\
\hline Raised bed + RT $T^{x}$ & $6.3 \mathrm{a}$ & $12.6 \mathrm{~b}$ & $36.2 \mathrm{a}$ & $1.6 \mathrm{a}$ & $56.4 \mathrm{a}$ & $41 \mathrm{a}$ & $248 \mathrm{a}$ \\
\hline No bed & $9.1 \mathrm{a}$ & $14.4 \mathrm{ab}$ & $25.9 \mathrm{~b}$ & $1.5 \mathrm{a}$ & $50.9 \mathrm{a}$ & 45 & $230 \mathrm{a}$ \\
\hline No bed + RT & $10.2 \mathrm{a}$ & $15.8 \mathrm{a}$ & $29.3 \mathrm{ab}$ & $1.5 \mathrm{a}$ & $56.9 \mathrm{a}$ & $49 \mathrm{a}$ & $250 \mathrm{a}$ \\
\hline
\end{tabular}

${ }^{2}$ Bulbs were separated according to quality: marketable bulbs without blemishes (No. 1); unmarketable split bulbs and diseased bulbs as culls. The No. 1 bulbs were graded according to diameter: small $(<2.25$ inches $)$, medium (2.25-3 inches), large ( $>3$ inches); 1 inch $=25.4 \mathrm{~mm}$.

l $1 \mathrm{Mg} \cdot \mathrm{ha}^{-1}=0.4461 \mathrm{ton} / \mathrm{acre} ; 1000 \mathrm{bulbs} / \mathrm{ha}=404.7 \mathrm{bulbs} / \mathrm{acre}$.

${ }^{x} \mathrm{RT}=$ reservoir tillage.

"Means within column followed by the same letter are not significantly different according to Fishers protected least significant difference test at $P \leq 0.05$.

Table 2. The effect of companion crop and environment on onion yield and grade at Carrington, N.Dak., during 2002 and 2003, and Absaraka, N.Dak., during 2003.

\begin{tabular}{|c|c|c|c|c|c|}
\hline \multirow{2}{*}{$\begin{array}{l}\text { Companion } \\
\text { crop }\end{array}$} & \multicolumn{5}{|c|}{ Onion yield ${ }^{\mathrm{z}}$} \\
\hline & Small & Medium & Large & Cull & Total \\
\hline \multicolumn{6}{|c|}{ - } \\
\hline \multicolumn{6}{|c|}{ Carrington 2002} \\
\hline No $\operatorname{crop}^{x}$ & $0.8 c^{\mathrm{w}}$ & $12.8 \mathrm{a}$ & $22.6 \mathrm{a}$ & $0.09 \mathrm{a}$ & $36.2 \mathrm{a}$ \\
\hline Barley & $2.8 \mathrm{~b}$ & $15.3 \mathrm{a}$ & $14.3 \mathrm{~b}$ & $0.10 \mathrm{a}$ & $32.3 \mathrm{a}$ \\
\hline Canola & $4.0 \mathrm{a}$ & $7.7 \mathrm{~b}$ & $0.5 \mathrm{c}$ & $0.06 \mathrm{a}$ & $12.3 \mathrm{~b}$ \\
\hline \multicolumn{6}{|c|}{ Carrington 2003} \\
\hline No crop & $0.2 \mathrm{a}$ & $3.6 \mathrm{~b}$ & $72.6 \mathrm{a}$ & $0.3 \mathrm{a}$ & $75.6 \mathrm{a}$ \\
\hline Barley & $0.5 \mathrm{ab}$ & $4.1 \mathrm{~b}$ & $73.7 \mathrm{a}$ & $0.2 \mathrm{a}$ & $78.3 \mathrm{a}$ \\
\hline Canola & $0.7 \mathrm{~b}$ & $6.3 \mathrm{a}$ & $49.0 \mathrm{~b}$ & $0.4 \mathrm{a}$ & $56.0 \mathrm{~b}$ \\
\hline \multicolumn{6}{|c|}{ Absaraka 2003} \\
\hline No crop & $18.1 \mathrm{a}$ & $25.0 \mathrm{a}$ & $20.1 \mathrm{a}$ & $2.6 \mathrm{~b}$ & $65.7 \mathrm{a}$ \\
\hline Barley & $16.4 \mathrm{a}$ & $20.2 \mathrm{a}$ & $17.4 \mathrm{ab}$ & $3.2 \mathrm{ab}$ & $57.1 \mathrm{ab}$ \\
\hline Canola & $18.3 \mathrm{a}$ & $18.3 \mathrm{a}$ & $10.7 \mathrm{~b}$ & $5.1 \mathrm{a}$ & $52.4 \mathrm{~b}$ \\
\hline $\begin{array}{l}{ }^{2} \text { Bulbs were sepa } \\
\text { 1); unmarketable } \\
\text { according to dia } \\
\text { inches); } 1 \text { inch }= \\
\text { "1 Mg.ha }{ }^{-1}=0.4 \\
\text { "No crop indicat } \\
\text { "Means within a }\end{array}$ & $\begin{array}{l}\text { ted accord } \\
\text { plit bulbs a } \\
\text { heter: smal } \\
5.4 \mathrm{~mm} \text {. } \\
61 \text { ton/acr } \\
\text { that no co }\end{array}$ & $\begin{array}{l}\text { to quality: } \mathrm{m} \\
\text { diseased bul } \\
<2.25 \text { inches }\end{array}$ & $\begin{array}{l}\text { ketable bul } \\
\text { as culls. Th } \\
\text { medium ( }\end{array}$ & $\begin{array}{l}\text { without } \\
\text { No. } 1 \text { bul } \\
25-3 \text { inc }\end{array}$ & $\begin{array}{l}\text { mishes (No } \\
\text { were gradec } \\
), \text { large }(>\end{array}$ \\
\hline
\end{tabular}

contributed to the 2 -fold total yield increase compared to 2002.

Total number of harvested plants, and small- and medium-sized bulb yields were similar for all companion treatments at Absaraka in 2003 (Table 2 ). Fewer large-sized bulbs in the canola treatment compared to no-companion crop contributed to the total yield differences. More onions with diameters greater than 3.5 inches (data not shown) may have contributed to the lower percentage of single centers in the no-companion crop treatment, but it seems unlikely that this was the only factor influencing double-center formation.

Barley had been shown to be a good short-term companion crop for onion. Greenland (2000) reported that barley planted in rows parallel to the onion rows reduced soil erosion, protected onion from wind damage, and did not reduce onion size or yield as long as it was not allowed to grow taller than $18 \mathrm{~cm}$. Results from the current study reinforce those of Greenland (2000), but also suggest that other planting or control methods should be investigated so that a longer application window is available in case of rainfall delays.

Canola provided good protection from wind damage, but by the time onion was at the required two-leafstage for postemergence broadleaf herbicide 
applications, the canola was beyond the recommended size for control by bromoxynil and oxyfluorfen. Canola plants (height $>91 \mathrm{~cm}$ ) also shaded nearby onion plants. A crucifera flea beetle (Phyllotreta cruciferae) outbreak at Absaraka defoliated most of the canola and reduced the competitive effects observed at Carrington. However, lack of broadleaf control options before onion reaches the two true-leaf stage eliminates canola as a possible companion crop in onion.

Results from this study showed that raised beds do not increase total onion yield compared to no-bed configuration from conventional planting on flat ground. However, more large-sized bulbs were produced in raised bed with reservoir tillage than the no-bed configuration; the no-bed configuration also resulted in more small-sized bulbs. Shock et al. (2004) showed that the highest gross returns do not necessarily correspond with the highest marketable yields due to the variation in price by size class. Onions with diameters greater than 4.25 inches have the highest value per weight; thus, production methods that increase bulb size would be beneficial to growers. Reservoir tillage may help to improve bulb size, but further investigations must be conducted to relate reservoirs from a spade to those from a paddle diker. Barley is a good companion crop to reduce wind damage in onion, but correct herbicide application timing is critical to prevent onion yield reduction. The competitive nature of canola and lack of chemical control options in onion greatly restrict its usefulness as a companion crop for onion. However, dwarf-type rapeseed cultivars should be investigated before the idea of using a fast-growing cool-season broadleaf companion crop is excluded.

\section{Literature cited}

Alva, A.K., T. Hodges, R.A. Boydston, and H.P. Collins. 2002. Effects of irrigation and tillage practices on yield of potato under high production conditions in the Pacific Northwest. Commun. Soil Sci. Plant Anal. 33:1451-1460.

Bhattarai, S.P. and P.P. Subedi. 1996. Normal season onion variety, nutrition and management trial at outreach research sites during 1993/1994 season. Lumle Reg. Agr. Res. Centre Working Paper 96:1-49.

Bracy, R.P., R.L. Parish, P.E. Bergeron, and R.J. Constantin. 1993. Comparison of flat and rounded planting bed for vegetable crops. Appl. Eng. Agr. 9:271-275.

Cavero, J., R.G. Ortega, and C. Zaragoza. 1996. Clear plastic mulch improved seedling emergence of direct-seeded pepper. HortScience 31:70-73.

Fahong, W., W. Xuqing, and K. Sayre. 2003. Comparison of conventional, flood irrigated, flat planting with furrow irrigated, raisedbed planting for winter wheat in China. Field Crops Res. 87:35-42.

Greenland, R.G. 2000. Optimum height at which to kill barley used as a living mulch in onions. HortScience 35:853-855.

Howell, T.A., A.D. Schneider, and D.A. Dusek. 2002. Effects of furrow diking on corn response to limited and full sprinkler irrigation. Soil Sci. Soc. Amer. J. 66:222-227.

Jones, O.R. and B.A. Stewart. 1990. Basin tillage. Soil Tillage Res. 18:249-265.

Kumar, A., R. Singh, R.K. Chhillar, and M. Pal. 2001. Influence of fertility levels and support management on tomato (Lycopersicon esculentum Miller) under different planting methods. Crop Res. 22:437-441.
Locher, J., A. Ombodi, T. Kassai, T. Tornyai, and J. Dimeny. 2003. Effects of black plastic mulch and raisedbed on soil temperature and yield of sweet pepper. Intl. J. Hort. Sci. 9:3-4, 107-110.

Mascagni, H.J., T.C. Deisling, W.E. Sabbe, M. May, L.R. Oliver, and E.D. Vories. 1995. Wheat production on raisedbeds on clayey and silt loam soils. Commun. Soil Sci Plant Anal. 26(3-4):503-513.

McIntosh, M.S. 1983. Analysis of combined experiments. Agron. J. 75:153-155.

Russo, V.M. 1995. Bedding, plant population, and spray-on mulch tested to increase dry bean yield. HortScience 30:53-54.

Sharma, A.K., R.K. Sharma, and K. Srinivasa Babu. 2004. Effect of planting options and irrigation schedules on development of powdery mildew and yield of wheat in the north western plains of India. Crop Protection 23:249-253.

Sharma, R.K. and V.K. Saxena. 2002. Influence of sowing methods on productivity of maize (Zea mays). Indian J. Agr. Sci. 72:651-653.

Shock, C.C., E.B.G. Feibert, and L.D. Saunders. 2004. Plant population and nitrogen fertilization for subsurface dripirrigated onion. HortScience 39:17221727.

Wilkes, L.H. and P. Hobgood. 1969. A new approach to field crop production. Trans. Amer. Soc. Agr. Eng. 12:529-532. 